\title{
PENGEMBANGAN RANCANGAN PENDIDIKAN KARAKTER MELALUI PEMBELAJARAN MATA PELAJARAN PENDIDIKAN KEWARGANEGARAAN DI SEKOLAH DASAR
}

\author{
Nawaji \\ UPTD TK, SD dan PLS Dinas Pendidikan Kec. Lawang Kab. Malang \\ Jl. Thamrin No. 31 Lawang, HP. 081333945113 \\ Email:nawajipomo@gmail.com
}

\begin{abstract}
Abstrak: tujuan pengembangan ini adalah untuk menghasilkan produk rancangan pelaksanaan pendidikan karakter yang diintegrasikan dalam mata pelajaran PKn di sekolah dasar. Prosedur pengembangan ini menggunakan model prosedural yang bersifat deskriptif. Hasil pengembangan menunjukkan bahwa nilai-nilai karakter yang diintegrasikan dalam RPP meliputi: trustworthines, respect, dilligence, responsibility, courage, integrity, caring, fairness and citizenship. Disimpulkan bahwa rancangan pelaksanaan pendidikan karakter yang diintegrasikan dalam pembelajaran mata pelajaran PKn yang disusun pengembang dapat diterapkan pada siswa Kelas VI di sekolah dasar. Disarankan untuk diseminasi produk ke sasaran yang lebih luas. Di samping itu, juga perlu dikembangkan lebih lanjut model penilaian pendidikan karakter di sekolah dasar.
\end{abstract}

Kata kunci: rancangan pembelajaran, pendidikan karakter, pendidikan kewarganegaraan.

\begin{abstract}
The purpose of this development is to produce the design of an integrated character education in the subjects of Moral Education in elementary school. The development procedure using a procedural model that is descriptive. The results show that the developments of character values that are integrated in the lesson plans include: trustworthines, respect, dilligence, responsibility, courage, integrity, caring, fairness and citizenship. It was concluded that the design of an integrated character education in the learning of subjects Civics compiled developer can be applied to the Class VI student in elementary school. It is advisable for the dissemination of the products to the broader target. In addition, it also needs to be further developed valuation models of character education in primary schools.
\end{abstract}

Keywords: learning design, character education, citizenship education lesson

Pendidikan dianggap belum berkarakter dan belum mampu melahirkan warga negara yang berkualitas, baik prestasi maupun perilaku. Oleh karena itu, Kemendikbud mengembangkan grand design pendidikan karakter untuk setiap jalur, jenjang dan jenis satuan pendidikan (Wulandari, dkk., 2013). Pendidikan karakter bertujuan membentuk bangsa yang tangguh, kompetitif, berakhlak mulia, bermoral, bertoleran, bergotong royong, berjiwa patriotik, berkembang dinamis, berorientasi ilmu pengetahuan dan teknologi, yang semuanya dijiwai oleh iman dan takwa kepada Tuhan yang Maha Esa berdasarkan Pancasila. Pendidikan karakter berfungsi: (1) mengembangkan potensi dasar agar berhati baik, berpikiran baik, dan berperilaku baik; (2) memperkuat dan membangun perilaku bangsa yang bhineka; dan (3) meningkatkan peradaban bangsa yang kompetitif dalam pergaulan dunia (Ferdiawan \& Putra, 2014).

Menurut Asmani (2012) pendidikan karakter sangat efektif diterapkan di sekolah. Lingkungan sekolah (guru dan siswa) memiliki peran yang kuat dalam membentuk karakter anak 
(Mulyatiningsih, 2011). Peserta didik lebih banyak menghabiskan waktunya di sekolah daripada di tempat lain. Oleh karena itu, sekolah menjadi tempat pembentukan karakter bagi para peserta didik.

Permasalahannya, sampai saat ini belum diketahui sampai sejauh mana model penerapan praktik pendidikan karakter yang dikembangkan oleh guru, khususnya di Sekolah Dasar. Menurut Budiastuti (2010) pendidikan dianggap belum berkarakter dan belum mampu melahirkan warga negara yang berkualitas, baik prestasi maupun perilaku.

Kesuma, dkk. (2012) mengidentifikasi faktanya menunjukkan bahwa kecenderungan KBM yang terjadi di kelas-kelas tidak menunjukkan pendidikan karakter. Tetapi lebih menunjukkan sebagai pengajaran. Indikator yang dapat mencirikan hal tersebut adalah: (1) desain silabus dan RPP yang dibuat guru-guru saat ini cenderung berpusat pada guru, bukan pada peserta didik; (2) hirarki perilaku yang dirancang dalam silabus dan RPP cenderung berada pada perilaku tingkat rendah, peserta didik dipaksa untuk mengingat banyak fakta, bahkan minim dengan pemahaman dan aplikasi konsep, (3) KBM yang terjadi sering tidak kontekstual dengan kehidupan peserta didik, bahkan verbalisme banyak menjadi keunggulan para guru saat ini, (4) metode pembelajaran yang banyak dilakukan cenderung ceramah tunggal, peserta didik yang baik dipersepsi sebagai anak yang mendengarkan dan mampu mengulang apa yang diceramahkan oleh gurunya, dan (5) evaluasi akhir jarang dilakukan, ketika dilakukan informasi dari hasil evaluasi jarang ditindaklanjuti, penyebab hal ini adalah karena jumlah peserta didik yang cukup besar (40 peserta didik/kelas) dalam kelasnya.

Berdasarkan pemaparan temuan Kesuma, dkk. (2012) dapat dikemukakan bahwa dalam pembelajaran pendidikan karakter di sekolah faktanya belum menunjukkan hasil sesuai dengan yang diharapkan, baik mulai desainnya dalam silabus atau RPP, perumusannya dalam perilaku yang dirancang, belum kontekstual dan terutama pada rancangan pembelajaran yang dilakukan oleh guru masih cenderung berorientasi pada ceramah tunggal. Temuan Akbar (2010) dalam penelitiannya menunjukkan bahwa pelaksanaan pendidikan nilai dan karakter tersebut belum optimal. Hal ini dikarenakan pelaksanaannya belum dilakukan secara sistematik, terprogram secara khusus, dan belum maksimal sesuai prinsip-prinsip pendidikan nilai dan karakter.

Sementara itu, berdasarkan pengamatan peneliti dalam studi pendahuluan di sekolah dasar di Kecamatan Lawang Kabupaten Malang, pendidikan karakter telah diterapkan dalam kegiatan belajar mengajar. Sekolah dasar yang telah menerapkan pendidikan karakter tersebut antara lain adalah SDN Lawang 05 dan SDK ST. Fransiskus di Kecamatan Lawang Kabupaten Malang.

Di SDN Lawang 05, Kepala Sekolahnya yaitu Bapak Mochamad Saeni mengemukakan bahwa dalammengembangkanpendidikankarakterdalam mata pelajaran Pendidikan Kewarganegaraan dalam kegiatan belajar mengajar melalui mata pelajaran Pendidikan Kewarganegaraan dengan cara sekolah menyusun silabus berdasarkan nilainilai pendidikan karakter, pekerti bangsa dan memetakan sesuai dengan jenjang/tingkat kelas. Demikian pula dalam memilih metode yang sesuai untuk mengajarkan pendidikan karakter bagi peserta didik melalui mata pelajaran Pendidikan Kewarganegaraan, guru diberikan pengarahan/ bimbingan.

Sedangkan sekolah dasar lainnya, adalah SDK ST. Fransiskus, menurut Sr. M..Yuvientia S.,SPM, SPd tentang penerapan pendidikan karakter di sekolah dikemukakannya bahwa pendidikan karakter diusahakan untuk dapat dimasukkan dalam setiap pembelajaran bukan hanya dalam bidang studi Pendidikan Kewarganegaraan saja. Di sekolah, disamping kepala sekolah, guru mempunyai peranan yang sangat penting sebagai pengelola pembelajaran. Sebagai pengelola pembelajaran (learning manager), Agustian (2009) menekankan agar kita tidak terlalu menekankan pembelajaran intelektualistis-kognitif dan mengabaikan faktor afektif. Oleh karena itu, perlu adanya self-mastery dalam diri anak untuk menangkap signyal-signyal yang agung dalam hati nurani-haruslah diajarkan dan dilatihkan. Tantangan pendidikan tidak hanya persoalan akademis, tetapi juga akhlak dan karakter bangsa (Agung, dkk., 2011).

Sebenarnya penelitian-penelitian yang mengangkat tema tentang pendidikan karakter sudah dilaksanakan. Namun demikian yang mengkaji tentang pembelajaran yang terkait dengan pengembangan rancangan pendidikan 
karakter belum banyak diteliti. Fitriah (2011) dalam penelitiannya mendeskripsikan: (1) proses perencanaan pendidikan karakter di SD, (2) proses pelaksanaan pendidikan karakter di SD, (3) proses evaluasi pendidikan karakter di SD. Hasil penelitian antara lain: dari aspek perencanaan meliputi: (1) merancang kondisi sekolah yang kondusif, (2) merancang kurikulum pendidikan karakter secara eksplisit, (3) menciptakan kurikulum karakter yang integratif, (4) pengelolaan ruang kelas, (5) pengelolaan lingkungan luar kelas. Pada tataran pelaksanaannya, diantaranya:(1) kerjasamaantara warga sekolah, (2) menerapkan keteladanan, (5) pembiasaan sholat berjamaah, (4) pembinaan alqur'an yang intensif, (5) menghargai kreatifitas peserta didik, (6) menjalin hubungan harmonis antara guru dan peserta didik. Pada tataran evaluasi: (1) kerjasama dengan orang tua peserta didik (co parenting), (2) pengawasan yang ketat terhadap akhlak, (3) home visit (kunjungan rumah), dan (4) menerbitkan buku bina Ibadah dan buku penghubung.

Penelitian Marzuki (2013) menunjukkan bahwa nilai yang ditekankan dalam pendidikan karakter di SD Muhammadiyah Manyar adalah nilai religius disamping nilai kemandirian dan kepedulian. Kebijakan yang diambil agar pendidikan karakter berhasil optimal meliputi tiga hal: (1) menyangkut pembelajaran seperti pemberian jam lebih banyak pada mata pelajaran keagamaan, (2) menyangkut hal diluar pembelajaran seperti pengadaan buku my diary, dan (3) menyangkut guru/karyawan seperti pembinaan guru. Kepala Sekolah telah merancang berbagai kegiatan dalam program kerjanya seperti pembinaan siswa, pengadaan shalat berjamaah, dan kerjasama dengan wali siswa. Pendidikan karakter di SD Muhammadiyah Manyar dilaksanakan di dalam dan di luar kelas. Pendidikan di kelas dilakukan dengan model dan strategi terintegrasi yaitu mengintegrasikan semua mata pelajaran dengan nilai karakter serta mempola perilaku guru-siswa yang terintegrasi dengan muatan karakter dalam kegiatan seharihari. Pendekatan yang digunakan adalah pendekatan nilai (inculcation approach) yaitu pendekatan yang menggunakan keteladanan dalam proses pembelajaranya seperti aktivitas beribadah di sekolah. Pendidikan karakter di luar kelas dilakukan melalui outbound, outdoor, ekstra kurikuler, dan pembiasaan (habituasi) beribadah. Pembiasaan yang dilakukan secara terus menerus akan menjadi budaya sehingga peserta didik akan terbiasa berperilaku positif.

Penelitian Zuchdi, dkk. (2006) pada semua jenjang pendidikan di Daerah Istimewa Yogyakarta menunjukkan hasil antara lain bahwa: (1) konteks institusional sekolah masih belum secara optimal mendukung pelaksanaan pendidikan karakter; (2) strategi indoktrinasi masih digunakan meskipun porsinya tidak terlalu besar, kadar pemberian teladan masih perlu ditambah; fasilitasi nilai yang sangat sesuai untuk melatih kemampuan membuat keputusan justru tidak digunakan, pengembangan keterampilan hidup (soft skills) yang terkait dengan nilai dan moralitas juga belum maksimal; dan (3) iklim pendidikan karakter belum sepenuhnya kondusif. Beberapa saran yang dikemukakan oleh Zuchdi, dkk. (2006) dari hasil penelitian tersebut antara lain: (1) setiap lembaga pendidikan mulai dari taman kanak-kanak sampai sekolah menengah atas, bahkan perguruan tinggi hendaknya memiliki program pendidikan karakter yang terintegrasi dengan semua bidang studi melalui kegiatan baik intra maupun ekstrakurikuler; dan (2) konteks institusional sekolah dan iklim pembelajaran harus kondusif untuk pembentukan karakter.

Walaupun penelitian-penelitian tersebut masing-masing telah mengkaji tentang pendidikan karakter di sekolah dasar, namun belum sampai mengidentifikasi bagaimana rancangan pendidikan karakter yang efektif. Khususnya diintegrasikan dalam pembelajaran mata pelajaran Pendidikan Kewarganegaraan di sekolah dasar sebagaimana yang akan diteliti dalam penelitian ini. Berdasarkan studi pendahuluan diperoleh informasi belum teridentifikasi bagaimana model pendidikan karakter yang efektif diterapkan di sekolah dasar. Hal ini sesuai dengan yang dikemukakan oleh Ghufron (2011) bahwa pendidikan karakter masih terkesan diwacanakan. Sementara itu, menurut Amri, Jauhari \& Elisah (2011) para pakar pendidikan umumnya sependapat tentang pentingnya upaya peningkatan pendidikan karakter pada jalur pendidikan formal. Namun demikian, ada perbedaan-perbedaan pendapat diantara mereka tentang pendekatan dan modus pendidikannya.

Suparno, dkk. (2002) menawarkan penyam- 
paian pembelajaran moral dan budi pekerti melalui rancangan pembelajaran terintegrasi yang akan lebih memudahkan penanaman budi pekerti dan efektif karena semua guru terlibat dalam menanamkan nilai moral dan budi pekerti melalui mata pelajaran yang diampunya. Akan tetapi, kenyataannya di sekolah guru kesulitan dalam merancang materi pembelajaran yang mengintegrasikan nilai-nilai karakter.

Bertitik tolak dari uraian tersebut, apabila dianalisa maka dapat dikemukakan bahwa pendidikan karakter pada jenjang sekolah dasar mempunyai peranan yang sangat strategis. Dikatakan strategis, oleh karena peserta didik usia SD/MI mempunyai standar pembiasaan yang lebih besar dibanding jenjang yang lebih tinggi. Dikemukakan oleh Aman \& Isa (2014) bahwa karakter terbentuk karena pembiasaan sikap terpuji dan kiranya sangat tepat jika porsi ditetapkan standarnya, misalnya: untuk PAUD/ TK, pembiasaan $90 \%$ dan pengetahuan $10 \%$; untuk SD/MI, pembiasaan $80 \%$ dan pengetahuan $20 \%$; untuk SMP/MTs, pembiasaan $60 \%$ dan pengetahuan $40 \%$; untuk SMA/MA/SMK, pembiasaan $20 \%$ dan pengetahuan $80 \%$; dan untuk Perguruan Tinggi, pembiasaan $10 \%$ dan pengetahuan $90 \%$.

Implementasi pendidikan karakter pada jenjang sekolah dasar porsinya mencapai $60 \%$ dibandingkan dengan jenjang pendidikan lainnya. Hal tersebut dikarenakan agar lebih mudah diajarkan dan melekat di jiwa anak-anak tersebut hingga kelak ia dewasa. Disamping itu, pada usia dini 0-6 tahun, otak berkembang sangat cepat hingga $80 \%$. Oleh karena itu, banyak yang menyebut masa tersebut sebagai masa-masa emas anak (golden age) (Chou, Yan \& Huang, 2014).

Berdasarkan analisis di atas, pelaksanaan pendidikan karakter di sekolah dasar terkendala oleh hal-hal sebagai berikut: (1) pendidikan karakter harus dipraktekkan, titik beratnya bukan pada teori; (2) upaya pengembangan pada jenjang pendidikan dasar sifatnya belum menyeluruh; (3) pendidikan karakter sebenarnya sudah ada dalam kurikulum, tetapi selama ini tidak dikedepankan dan diajarkan secara tersurat; (4) pendidikan yang berhubungan dengan kepribadian atau akhlak tidak dapat diajarkan dalam bentuk pengetahuan saja, tetapi perlu adanya pembiasaan dalam perilaku sehari-hari; dan (5) desain silabus dan RPP yang dibuat guru-guru saat ini cenderung berpusat pada guru, bukan pada peserta didik.

Pembelajaran pendidikan karakter di sekolah faktanya belum menunjukkan hasil sesuai dengan yang diharapkan, baik mulai desainnya dalam silabus atau RPP, perumusannya dalam perilaku yang dirancang, belum kontekstual dan terutama pada metode pembelajaran yang dilakukan oleh guru masih cenderung berorientasi pada ceramah tunggal. Menurut Nuryatin (2014) guru dalam mengajar juga belum mempersiapkan diri dengan menyusun Rencana Pelaksanaan Pembelajaran, serta belum menerapkan pendidikan karakter secara jelas.

Pembelajaran, secara sederhana dapat diartikan sebagai upaya untuk membelajarkan siswa dan aktivitas belajar siswa tersebut dapat terjadi dengan direncanakan (by designed). Perencanaan merupakan aktivitas pendidikan dimana pembelajaran ada didalamnya yang secara sadar dirancang untuk membantu siswa dalam mengembangkan potensi dirinya melalui sejumlah kompetensi yang diacunya dalam setiap proses pembelajaran yang diikutinya. Perencanaan berarti menyusun langkah-langkah penyelesaian suatu masalah atau pelaksanaan suatu pekerjaan yang terarah pada pencapaian tujuan tertentu (Nawawi, 1983). Kesimpulannya, efektivitas perencanaan berkaitan dengan penyusunan rangkaian kegiatan untuk mencapai tujuan, dapat diukur dengan terpenuhinya apa yang tertuang dalam perumusan perencanaan pelaksanaan pembelajaran.

Dengan demikian permasalahan utama pendidikan karakter di sekolah dasar adalah pada tataran desain atau RPPyang dibuat oleh guru. RPP yang dibuat oleh guru masih cenderung berpusat pada guru, bukan pada peserta didik. Demikian pula perilaku yang dirancang dalam RPP/ desain guru perumusannya belum kontekstual dan terutama pada metode pembelajaran yang dilakukan guru masih cenderung berorientasi pada ceramah tunggal.

Berdasarkan latar belakang masalah di atas, maka perlu dikaji lebih lanjut dalam pengembangan ini yaitu "Pengembangan Rancangan Pendidikan Karakter melalui Pembelajaran Mata Pelajaran Pendidikan Kewarganegaraan di Sekolah Dasar." Sedangkan lokasi penelitian dan pengembangan ini adalah di SDN Lawang 5 dan SDK ST. Fransiskus di Kecamatan Lawang Kabupaten Malang. Tujuan 
pengembangan adalah untuk menghasilkan rancangan pendidikan karakter yang dapat diterapkan terhadap peserta didik di sekolah dasar pada kelas-kelas tinggi di sekolah dasar negeri maupun swasta di Kecamatan Lawang Kabupaten Malang dengan mengintegrasikan pada perencanaan pembelajaran mata pelajaran Pendidikan Kewarganegaraan bagi peserta didik Kelas VI di Sekolah Dasar.

\section{METODE}

Penelitian dan pengembangan yang dilakukan adalah untuk menghasilkan produk berupa perencanaan pembelajaran pendidikan karakter yang diintegrasikan dalam pembelajaran mata pelajaran Pendidikan Kewarganegaraan. Prosedur penelitian dan pengembangan dari Borg \& Gall (1979) disederhanakan kedalam langkah-langkah sebagai berikut: studi awal (prasurvey), perencanaan, implementasi dan evaluasi/revisi rancangan. Studi awal dilakukan untuk mengidentifikasi permasalahan yang ada, perencanaan dilakukan untuk menyusun produk yang akan dikembangkan yaitu berupa rencana pelaksanaan pembelajaran pendidikan karakter melalui pembelajaran Pendidikan Kewarganegaraan dan evaluasi produk setelah diimplementasikan.

Uji pengembangan produk dalam penelitian ini pertama menggunakan desain penelitian deskriptif. Desain ini digunakan untuk uji ahli, telaah guru, dan tanggapan siswa. Kedua, desain uji lapangan. Subjek uji pengembangan produk penelitian ini adalah ahli mata pelajaran Pendidikan Kewarganegaraan, ahli teknologi pendidikan, ahli perencanaan pembelajaran, serta peserta didik dan guru SDN Lawang 5 dan SDK ST. Fransiskus.

Ada dua jenis data dalam penelitian ini. Pertama, data penelitian berupa data kualitatif, yaitu informasi yang diperoleh dari hasil studi pendahuluan, kedua, hasil dari uji coba. Sedangkan pengumpulan data dalam penelitian ini menggunakan teknik: (a) dokumentasi, (b) angket, dan (c) observasi. Data dalam pengembangan ini dianalisis dengan dua macam teknik analisis data sebagai berikut ini. Pertama, data dianalisis dengan cara kualitatif khususnya untuk data dari hasil dokumentasi, angket analisis kebutuhan, karakteristik siswa, dan hasil observasi. Kedua, data dianalisis secara kuantitatif, khususnya untuk data yang diperoleh dari hasil uji coba ahli, telaah guru, tanggapan siswa yang telah dikumpulkan dianalisis dengan menggunakan metode statistik deskriptif untuk melihat persentase jawaban dari para ahli, guru dan siswa pengguna terakhir berkenaan dengan aspek yang ditanyakan. Untuk keperluan ini peneliti memanfaatkan pendekatan yang digunakan dengan penelitian kuantitatif dengan rumus persentase.

\section{HASIL}

\section{Produk Pengembangan}

Produk perencanaan pelaksanaan pembelajaran tersebut dapat dideskirpsikan dalam Tabel 1 berikut ini.

\section{Penyajian Data Uji Coba}

Data uji coba pengembangan meliputi (1) uji ahli isi mata pelajaran Pendidikan Kewarganegaraan di sekolah dasar, (2) uji ahli desain media pembelajaran, (3) uji coba perorangan, (4) uji coba kelompok kecil, dan (5) uji coba kelompok besar. Data yang diperoleh dari uji Ahli Isi Mata Pelajaran Pendidikan Kewarganegaraan, hasilnya dapat dilihat sebagaimana Tabel 2 berikut ini.

\section{Sajian Data Hasil Penilaian Uji Coba Ahli Rancangan/Desain Pembelajaran terhadap Model Pendidikan Karakter yang Diintegrasikan dalam Mata Pelajaran Pendidikan Kewarganegaraan (Tahap II)}

Berikut ini adalah data hasil penilaian/ tanggapan ahli rancangan pembelajaran terhadap penggunaan rancangan pembelajaran perencanaan pembelajaran Model Pendidikan Karakter yang diintegrasikan dalam pembelajaran mata pelajaran Pendidikan Kewarganegaraan.

\section{Uji Coba Lapangan/Guru Mata Pelajaran (Tahap III)}

Data dari guru mata pelajaran Pendidikan Kewarganegaraan berupa data kualitatif yaitu 
Tabel 1 Rancangan Pendidikan Karakter yang Diintegrasikan dalam Perencanaan Pelaksanaan Pembelajaran Mata Pelajaran Pendidikan Kewarganegaraan Siswa Kelas VI di Sekolah Dasar

\begin{tabular}{|c|c|}
\hline Satuan Pendidikan & $\begin{array}{l}\text { SDN Lawang } 5 \text { Kecamatan Lawang Kabupaten Malang } \\
\text { SDK ST. Fransiskus Kecamatan Lawang Kabupaten Malang }\end{array}$ \\
\hline Mata Pelajaran & Pendidikan Kewarganegaraan \\
\hline Kelas & VI \\
\hline Semester & II \\
\hline Alokasi Waktu & $4 \times 40$ menit (2 pertemuan) \\
\hline Standar Kompetensi & 3. Memahami peran Indonesia dalam lingkungan negara-negara di AsiaTenggara. \\
\hline Kompetensi Dasar & 3.1 Menjelaskan pengertian kerja sama negara-negara Asia Tenggara. \\
\hline Tujuan Pembelajaran & $\begin{array}{l}\text { - } \quad \text { Siswa mampu menyebutkan pengertian kerjasama negara-negara ASEAN. } \\
\text { - } \quad \text { Siswa mampu menyebutkan nama para tokoh pendiri ASEAN. } \\
\text { - } \quad \text { Siswa mampu menyebutkan negara-negara ASEAN. } \\
\text { - } \quad \text { Siswa mampu menjelaskan arti lambang ASEAN. } \\
\text { - } \quad \text { Siswa mampu menyebutkan nama para tokoh yang pernah menjabat sebagai sekjen } \\
\text { ASEAN. } \\
\text { - } \quad \text { Siswa mampu menyebutkan tugas pokok sekretariat nasional ASEAN. } \\
\text { - } \quad \text { Siswa mampu menyebutkan langkah-langkah konkret yang telah dicapai ASEAN } \\
\text { dalam bidang ekonomi. } \\
\text { - Siswa mampu menyebutkan contoh bentuk kerjasama ASEAN yang telah tercapai } \\
\text { di bidang ekonomi. } \\
\text { - } \quad \text { Siswa mampu menyebutkan upaya-upaya ASEAN dalam mempererat hubungan } \\
\text { sosial satu sama lain. } \\
\text { - Siswa mampu menyebutkan upaya-upaya ASEAN dalam mempererat hubungan } \\
\text { sosial satu sama lain. } \\
\text { - Siswa mampu menyebutkan upaya-upaya ASEAN dalam melestarikan kebudayaan } \\
\text { negara anggotanya. } \\
\text { - Membuat kliping dengan teman kelompoknya masing-masing. }\end{array}$ \\
\hline $\begin{array}{l}\text { Karakter Siswa yang } \\
\text { Diharapkan }\end{array}$ & $\begin{array}{l}\text { Dapat dipercaya (trustworhines), rasa hormat dan perhatian (respect), tekun (dilli- } \\
\text { gence), tanggung jawab (responsibility), berani (courage), integritas (integrity), peduli } \\
\text { (caring), jujur (fairness) dan kewarganegaraan (citizenship). }\end{array}$ \\
\hline Materi Ajar & $\begin{array}{l}\text { - Sejarah ASEAN. } \\
\text { - Lambang ASEAN. } \\
\text { - Tujuan pokok pembentukan dan prinsip utama ASEAN. } \\
\text { - Dasar-dasar kerjasama untuk mencapai tujuan pokok. } \\
\text { - Struktur sekretariat ASEAN. } \\
\text { - Bidang politik dan keamanan. } \\
\text { - Bidang ekonomi. } \\
\text { - Bidang sosial budaya. }\end{array}$ \\
\hline $\begin{array}{l}\text { Pendekatan dan } \\
\text { Metode Pembelajaran }\end{array}$ & $\begin{array}{l}\text { - Pendekatan kontekstual. } \\
\text { - Pendekatan cooperatif learning. } \\
\text { - Diskusi dengan teman sebangku. } \\
\text { - Tanya jawab. } \\
\text { - Penugasan. }\end{array}$ \\
\hline $\begin{array}{l}\text { Langkah-langkah } \\
\text { Kegiatan }\end{array}$ & $\begin{array}{l}\text { Kegiatan Awal } \\
\text { - } \quad \text { Mengajak semua siswa berdoa sesuai dengan agama, presensi, apersepsi dan } \\
\text { kepercayaan masing-masing, untuk mengawali pelajaran. } \\
\text { - } \quad \text { Memberikan motivasi dan menjelaskan tujuan pembelajaran. } \\
\text { - } \quad \text { Membagikan lembar ujian yang sudah diperiksa dan dinilai. } \\
\text { - } \quad \text { Membahas sekilas soal-soal ujian pada pertemuan sebelumnya. }\end{array}$ \\
\hline
\end{tabular}




\begin{tabular}{|c|c|}
\hline & $\begin{array}{l}\text { Kegiatan Inti } \\
\text { Eksplorasi } \\
\text { Dalam kegiatan eksplorasi, guru : } \\
\text { - } \quad \text { Semua siswa diminta menyimak teks yang dibaca oleh siswa yang ditunjuk secara } \\
\text { bergiliran mengenai kerjasama antar negara di Asia Tenggara. } \\
\text { - } \quad \text { Guru menunjukkan peta Asia Tenggara dan meminta semua siswa mengamati } \\
\text { letak negara-negaranya. } \\
\text { - } \quad \text { Bersama-sama menyebutkan nama-nama negara ASEAN beserta ibu kotanya. } \\
\text { - } \quad \text { Bersama-sama menyebutkan pemimpin negaranya. } \\
\text { - } \quad \text { Guru menjelaskan sejarah ASEAN. } \\
\text { - } \quad \text { Guru menunjukkan lambang ASEAN dan meminta seluruh siswa untuk mengam- } \\
\text { atinya. } \\
\text { - Guru menjelaskan arti lambang ASEAN. } \\
\text { - Membahas struktur ASEAN } \\
\text { Elaborasi } \\
\text { Dalam kegiatan eksplorasi, guru : } \\
\text { - Menggambar peta ASEAN dan lambangnya. } \\
\text { - Memberikan contoh-contoh kerjasama ASEAN dalam berbagai bidang seperti } \\
\text { bidang politik dan keamanan, bidang ekonomi dan bidang sosial. } \\
\text { - Mendiskusikan dampak ASEAN bagi negara-negara anggotanya. } \\
\text { - Guru membagi siswa menjadi beberapa kelompok, kemudian menugaskan untuk } \\
\text { membuat klipping yang berhubungan dengan kerjasama ASEAN dalam berbagai } \\
\text { Kidang. } \\
\text { Konfirmasi } \\
\text { Dalam kegiatan konfirmasiasi, guru : } \\
\text { - Guru bertanya jawab tentang hal-hal yang belum diketahui siswa. } \\
\text { Guru bersama siswa bertanya jawab meluruskan kesalah pemahaman, memberi- } \\
\text { kan penguatan dan penyimpulan. }\end{array}$ \\
\hline & $\begin{array}{l}\text { Kegiatan Penutup } \\
\text { Dalam kegiatan penutup, guru: } \\
\text { - } \quad \text { Siswa dan guru bertanya jawab tentang materi yang telah dipelajari selama per- } \\
\text { temuan itu untuk mengetahui pencapaian Indikator Pencapaian Kompetensi dan } \\
\quad \text { Kompetensi Dasar. } \\
\text { - } \quad \text { Siswa dan guru membuat kesimpulan materi yang telah dipelajari. } \\
\text { - } \quad \text { Siswa dan guru berdoa sesuai dengan agama dan kepercayaan masing-masing. }\end{array}$ \\
\hline $\begin{array}{l}\text { Sumber/Bahan } \\
\text { Belajar }\end{array}$ & $\begin{array}{l}\text { - Peta ASEAN. } \\
\text { - Gambar lambang ASEAN. } \\
\text { - } \text { Buku paket (Buku Pendidikan Kewarganegaraan untuk Sekolah Dasar Kelas 6). } \\
\text { - } \text { Surat Kabar, dst. }\end{array}$ \\
\hline Penilaian & $\begin{array}{ll}\text { - } & \text { Indikator pencapaian kompetensi } \\
\text { - } & \text { Teknik penilaian } \\
\text { - } & \text { Bentuk instrumen } \\
\text { - } & \text { Bentuk soal }\end{array}$ \\
\hline
\end{tabular}

Tabel 2 Data Hasil Penilaian Ahli Isi Mata Pelajaran terhadap Perencanaan Pembelajaran Model Pembelajaran Pendidikan Karakter yang Diintegrasikan dalam Pembelajaran Mata Pelajaran Pendidikan Kewarganegaraan di Sekolah Dasar

\begin{tabular}{|c|c|c|c|c|c|c|c|}
\hline \multirow[t]{2}{*}{ No. } & \multirow[t]{2}{*}{ Aspek yang Dinilai } & \multicolumn{5}{|c|}{ Skor } & \multirow[t]{2}{*}{ Keterangan } \\
\hline & & 1 & 2 & 3 & 4 & 5 & \\
\hline \multicolumn{8}{|c|}{ A. Komponen Perencanaan Pembelajaran } \\
\hline 1. & $\begin{array}{l}\text { Identitas meliputi: TIU mata pelajaran, kelas, } \\
\text { semester dan alokasi waktu. }\end{array}$ & & & & $\sqrt{ }$ & & Baik \\
\hline 2 & $\begin{array}{l}\text { Langkah pembelajaran meliputi: pendahuluan, } \\
\text { kegiatan inti, dan penutup. }\end{array}$ & & & & $\sqrt{ }$ & & Baik \\
\hline
\end{tabular}




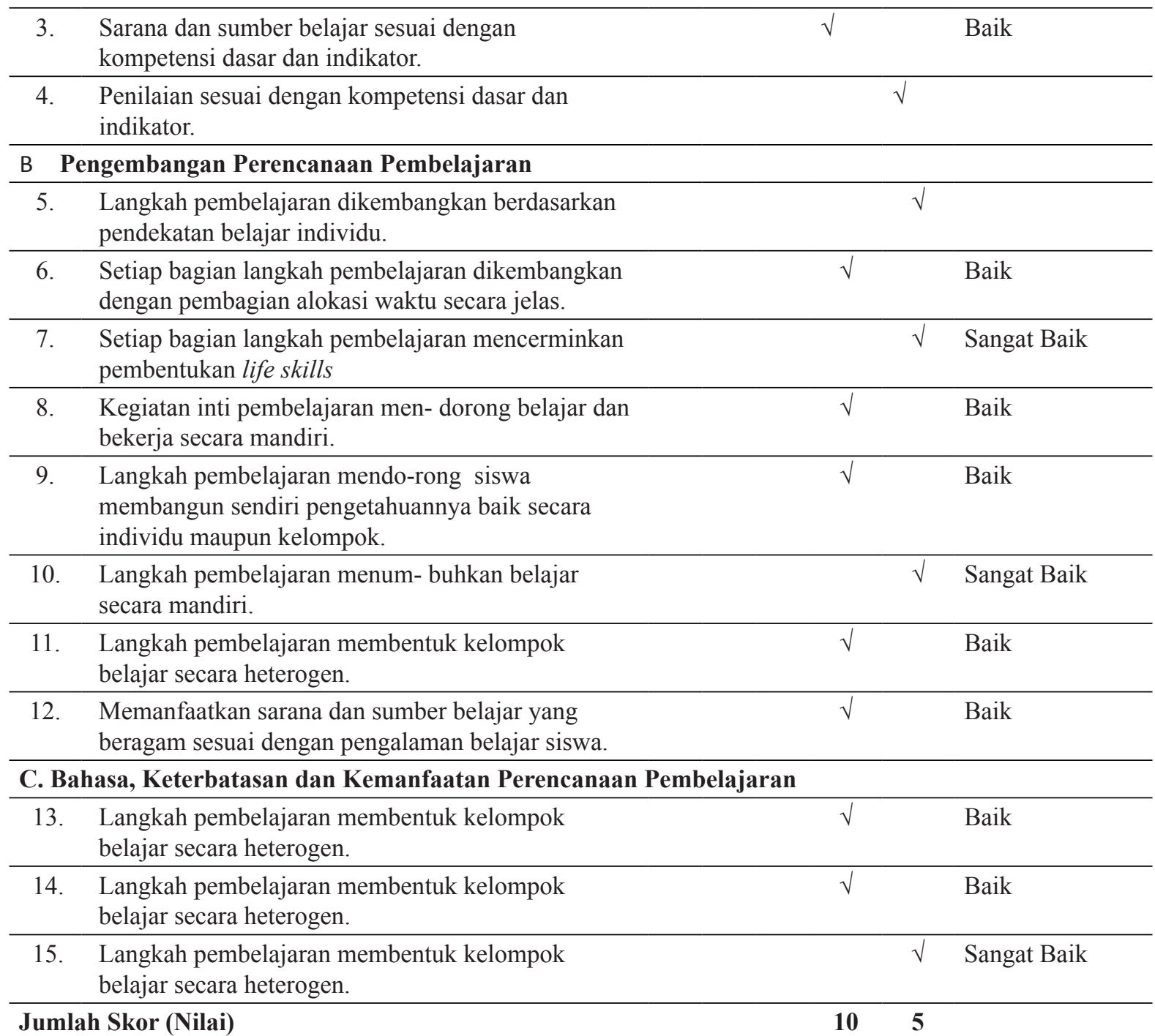

Sumber: data diolah dari lapangan.

\section{Keterangan:}

$\begin{array}{ll}5=\text { sangat baik } & 3=\text { cukup } \quad 1 \text { = sangat kurang } \\ 4=\text { baik } & 2=\text { kurang }\end{array}$

Tabel 3 Data Hasil Penilaian Uji Coba Ahli Rancangan/Desain Perencanaan Pembelajaran Model Pendidikan Karakter yang Diintegrasikan dalam Pembelajaran Mata Pelajaran Pendidikan Kewarganegaraan di Sekolah Dasar (Tahap II)

\begin{tabular}{|c|c|c|c|c|c|c|c|}
\hline \multirow[t]{2}{*}{ No. } & \multirow[t]{2}{*}{ Aspek yang Dinilai } & \multicolumn{5}{|c|}{ Skor } & \multirow[t]{2}{*}{ Keterangan } \\
\hline & & 1 & 2 & 3 & 4 & 5 & \\
\hline 1. & Kesesuaian dengan layout peencanaan pembelajaran & & & & $\sqrt{ }$ & & Baik \\
\hline 2 & Kesesuaian setting format paragraf & & & & $\sqrt{ }$ & & Baik \\
\hline 3 & Kesesuaian tata letak & & & $\sqrt{ }$ & & & Cukup \\
\hline 4 & Kesesuaian penggunaan materi & & & $\sqrt{ }$ & & & Cukup \\
\hline \multirow[t]{2}{*}{5} & Penggunaan format teks & & & & $\sqrt{ }$ & & Baik \\
\hline & Jumlah skor (nilai) & & & 2 & 3 & & \\
\hline
\end{tabular}

Sumber: data diolah dari lapangan.

Keterangan:

$\begin{array}{ll}5=\text { sangat baik } & 3=\text { cukup } \quad 1=\text { sangat kurang } \\ 4=\text { baik } & 2=\text { kurang }\end{array}$ 
komentar dan saran yang dihimpun menggunakan angket (Kode C). Pada angket tersebut tertera komentar secara langsung dari guru mata pelajaran Pendidikan Kewarganegaraan di Sekolah Dasar lokasi penelitian.

\section{Uji Coba Lapangan/Siswa (Tahap IV)}

Uji coba dilanjutkan dengan uji coba yang terakhir yaitu uji coba lapangan untuk siswa, baik kelompok kecil maupun kelompok besar. Berikut ini dipaparkan hasil tinjauan siswa secara kelompok kecil (5 siswa) terhadap perencanaan pembelajaran Pendidikan Kewarganegaraan. Komentar dan saran dari siswa akan digunakan sebagai pijakan untuk merevisi produk pengembangan perencanaan pembelajaran model pendidikan karakter yang diintegrasikan dalam pembelajaran mata pelajaran Pendidikan Kewarganegaraan di sekolah dasar.

Berikut ini dipaparkan hasil tinjauan siswa secara kelompok besar (30 siswa) terhadap perencanaan pembelajaran model pendidikan karakter yang diintegrasikan dalam pembelajaran mata pelajaran Pendidikan Kewarganegaraan. Komentar dan saran dari siswa akan digunakan sebagai pijakan untuk merevisi produk pengembangan perencanaan pembelajaran.

\section{Analisis Data}

Berdasarkan tabel 2, menunjukan bahwa hasil penilaian Ahli Isi mata pelajaran (penilaian tahap pertama), terhadap uraian isi pembelajaran pada perencanaan pembelajaran model pendidikan karakter yang diintegrasikan dalam pembelajaran mata pelajaran Pendidikan Kewarganegaraan, merupakan masukan yang berupa komentar dan saran dari ahli isi mata pelajaran terhadap isi perencanaan pembelajaran ini dijadikan sebagai dasar untuk memperbaiki sebelum dilakukan uji coba berikutnya (penilaian tahap kedua).

Berdasarkan hasil penilaian ahli isi mata pelajaran terhadap uraian isi pembelajaran pada perencanaan pembelajaran dinyatakan sudah sesuai/layak namun harus dilakukan revisi: mekanisme pembelajaran, materi di denah perencanaan pembelajaran lebih detailkan, kompetensi harus sesuai evaluasi. Walaupun demikian, berdasarkan penilaian ahli isi mata pelajaran secara umum dapat dikatakan baik dengan perolehan penilaian 10 baik dan 5 sangat baik. Selanjutnya uji coba berikutnya ditujukan kepada ahli desain/rancangan pembelajaran untuk menilai perencanaan pembelajaran model pendidikan karakter yang diintegrasikan dalam pembelajaran Pendidikan Kewarganegaraan.

Berdasarkan tabel 3 tersebut di muka, tentang data hasil uji coba ahli desain/rancangan perencanaan pembelajaran model pendidikan karakter yang diintegrasikan dalam pembelajaran mata pelajaran Pendidikan Kewarganegaraan dapat disimpulkan bahwa secara keseluruhan berdasarkan aspek-aspek yang dinilai, yaitu: (1) kesesuaian dengan layout perencanaan pembelajaran, (2) kesesuaian setting format paragraf, (3) kesesuaian tata letak, (4) kesesuaian penggunaan materi, dan (5) penggunaan format teks, dapat disimpulkan sementara bahwa menurut ahli desain/rancangan pembelajaran, produk pengembangan berupa produk perencanaan pembelajaran model pendidikan karakter yang disusun oleh pengembang yang diintegrasikan dalam pembelajaran mata pelajaran Pendidikan Kewarganegaraan bagi siswa Kelas VI di SDN Lawang 5 dan SDK ST. Fransiskus Kecamatan Lawang Kabupaten Malang sudah baik. Kesimpulan sementara ini dapat diperoleh dari aspek-aspek yang dinilai dalam uji coba oleh ahli desain/rancangan pembelajaran ada tiga aspek yang memperoleh nilai "Baik" yaitu tiga aspek: (1) kesesuaian dengan layout perencanaan pembelajaran, (2) kesesuaian setting format paragraf, dan (3) penggunaan format teks. Sedangkan dua aspek yang lainnya memperoleh nilai cukup, yaitu aspek (1) kesesuaian tata letak, dan (2) kesesuaian penggunaan materi.

Berdasarkan hasil penilaian ahli rancangan/ desain terhadap perencanaan pembelajaran model pendidikan karakter yang diintegrasikan dalam pembelajaran mata pelajaran Pendidikan Kewarganegaaan bagi siswa Kelas VI di SDN Lawang 5 dan SDK ST. Fransiskus Kecamatan Lawang Kabupaten Malang pada perencanaan pembelajaran dinyatakan sudah sesuai/layak namun harus dilakukan beberapa revisi sesuai dengan rekomendasi yang diberikan oleh ahli rancangan/desain pembelajaran.

Berdasarkan tabel 4 tentang Data Hasil Penilaian Guru Mata Pelajaran terhadap Model Pendidikan Karakter yang Diintegrasikan dalam Pembelajaran Mata Pelajaran Pendidikan 
Kewarganegaraan di Sekolah Dasar, dapat dianalisis sebagai berikut: (1) kerangka isi pembelajaran:(a)kejelasan kerangka perencanaan pembelajaran, (b) kemenarikan isi perencanaan pembelajaran; (2) tujuan pembelajaran: (a) kejelasan isi tujuan pembelajaran, (b) ketepatan rumusan-rumusan tujuan pembelajaran, (c) kejelasaasan bahasa yang digunakan dalam tujuan pembelajaran; (3) petunjuk penggunaan rencana pembelajaran: (a) kejelasan isi petunjuk, (b) kejelasan bahasa yang digunakan, dan (c) kejelasan fungsi petunjuk; (4) uraian isi pembelajaran: (a) kejelasan isi pembelajaran, (b) kejelasan ilustrasi, dan (c) kejelasan uraian isi pembelajaran dalam membantu menyelesaikan soal dalam mencapai tujuan; (5) soal latihan/ tugas dan kunci jawaban: (a) kejelasan tugas/ soal, (b) kejelasan bahasa yang digunakan, (c) kesesuaian jumlah soal, (d) kesesuaian kunci jawaban, dan (e) kejelasan kunci jawaban; dan (6) sumber/bahan belajar: (a) kesesuaian sumber/ bahan belajar, dan (b) ketepatan sumber/bahan belajar.

Sementara itu, berdasarkan skor penilaian dari uji coba dari guru mata pelajaran mata pelajaran Pendidikan Kewarganegaraan, diperoleh skor penilaian $=3,56$

Perolehan nilai 3,56 tersebut di atas kalau kita konfirmasikan dengan Skala Penilaian (Tanggapan) dapat dikategorikan sebagai skor/nilai "sesuai". Dengan demikian dapat diisimpulkan bahwa hasil uji coba penilaian dari guru mata pelajaran hasilnya bahwa produk perencanaan pembelajaran model pendidikan karater yang diintegrasikan dalam pembelajaran mata pelajaran Pendidikan Kewarganegaraan bagi siswa Kelas VI di SDN Lawang 5 dan SDK ST Fransiskus Kecamatan Lawang Kabupaten Malang, dapat dilaksanakan pada siswa sekolah dasar.

Berdasarkan tabel 5 tentang Data Hasil Penilaian Siswa (Kelompok Kecil) terhadap Model Pendidikan Karakter yang Diintegrasikan dalam Pembelajaran Mata Pelajaran Pendidikan Kewarganegaraan di Sekolah Dasar di atas, dapat dianalisis hal-hal sebagai berikut ini. Komponenkomponen secara umum sudah layak, Hal ini ditunjukkan oleh kualifikasi penilaian kelompok kecil (5 siswa) sebagai obyek uji coba kelompok kecil bahwa dari berbagai aspek yang dinilai, antara lain: (1) kerangka isi pembelajaran: kejelasan kerangka perencanaan pembelajaran, dan kemenarikan; (2) tujuan pembelajaran: kejelasan isi tujuan pembelajaranm ketepatan rumusan-rumusan tujuan pembelajaran, dan kejelasan bahasa yang digunakan dalam tujuan pembelajaran; (3) uraian isi pembelajaran: kejelasan isi pembelajaran, kejelasan ilustrasi, kejelasan uraian isi pembelajaran dalam membantu menyelesaikan soal dalam mencapai tujuan; (4) soal latihan/tugas dan kunci jawaban: kejelasan tugas/soal, kejelasan bahasa yang digunakan, kesesuaian jumlah soal, kesesuaian kunci jawaban, kejelasan kunci jawaban; dan (5) sumber/ bahan belajar. Masing-masing aspek tersebut di atas setelah dilakukan uji coba tinjauan dari siswa (kelompok kecil) hasilnya dapat dipaparkan berikut ini.

Sementara itu, berdasarkan skor penilaian dari uji coba dari tinjauan siswa (Kelompok Kecil) terhadap perencanaan pembelajaran pendidikan karakter yang diintegrasikan dalam pembelajaran mata pelajaran Pendidikan Kewarganegaraan siswa Kelas VI di SDN Lawang 5 dan SDK ST. Fransiskus Kecamatan Lawang Kabupaten Malang, diperoleh rekapitulasi skor penilaian 4.33. Perolehan nilai 4,33 tersebut di atas kalau kita konfirmasikan dengan Skala Penilaian (Tanggapan) dapat dikategorikan sebagai skor/ nilai "sangat sesuai/sangat jelas/sangat tepat". Dengan demikian dapat diisimpulkan bahwa hasil uji coba dari tinjauan siswa (Kelompok Kecil) terhadap produk perencanaan pembelajaran model pendidikan karater yang diintegrasikan dalam pembelajaran mata pelajaran Pendidikan Kewarganegaraan, dapat dilaksanakan pada siswa.

Berdasarkan uji coba kelompok kecil (5 siswa) sebagai hasil tabulasi dan hasil analisis diatas menunjukan bahwa keseluruhan komponen perencanaan pembelajaran model pendidikan karakter yang diintegrasikan dalam pembelajaran mata pelajaran Pendidikan Kewarganegaraan sudah memenuhui syarat untuk diterapkan terhadap siswa.

Berdasarkan table 6 tentang Data Hasil Penilaian Siswa (Kelompok Besar) terhadap perencanaan pelaksanaan pembelajaran Pendidikan Karakter yang diintegrasikan dalam Pembelajaran Mata Pelajaran Pendidikan Kewarganegaraan di Sekolah Dasar di atas, dapat dianalisis hal-hal sebagai berikut ini. 
Komponen-komponen secara umum sudah layak. Hal ini ditunjukkan oleh kualifikasi penilaian kelompok besar (30 siswa) sebagai obyek uji coba kelompok besar bahwa dari berbagai aspek yang dinilai, antara lain: (1) kerangka isi pembelajaran: kejelasan kerangka perencanaan pembelajaran, dan kemenarikan; (2) tujuan pembelajaran: kejelasan isi tujuan pembelajaranm ketepatan rumusan-rumusan tujuan pembelajaran, dan kejelasan bahasa yang digunakan dalam tujuan pembelajaran; (3) uraian isi pembelajaran: kejelasan isi pembelajaran, kejelasan ilustrasi, kejelasan uraian isi pembelajaran dalam membantu menyelesaikan soal dalam mencapai tujuan; (4) soal latihan/ tugas dan kunci jawaban: kejelasan tugas/soal, kejelasan bahasa yang digunakan, kesesuaian jumlah soal, kesesuaian kunci jawaban, kejelasan kunci jawaban; dan (5) sumber/ bahan belajar. Masing-masing aspek tersebut di atas setelah dilakukan uji coba tinjauan dari siswa (kelompok besar) hasilnya dapat dipaparkan berikut ini.

Sementara itu, berdasarkan skor penilaian dari uji coba dari tinjauan siswa (Kelompok Besar) terhadap perencanaan pembelajaran pendidikan karakter yang diintegrasikan dalam pembelajaran mata pelajaran Pendidikan Kewarganegaraan, diperoleh rekapitulasi skor penilaian 3,72. Perolehan nilai 3,72 tersebut di atas kalau kita konfirmasikan dengan Skala Penilaian (Tanggapan) dapat dikategorikan sebagai skor/nilai "sesuai/jelas/tepat". Dengan demikian dapat diisimpulkan bahwa hasil uji coba siswa (kelompok besar) bahwa produk perencanaan pembelajaran model pendidikan karater yang diintegrasikan dalam pembelajaran mata pelajaran Pendidikan Kewarganegaraan bagi siswa Kelas VI di SDN Lawang 5 dan SDK ST Fransiskus Kecamatan Lawang Kabupaten Malang, dapat dilaksanakan pada siswa.

Berdasarkan hasil analisa dari uji coba ahli isi, uji coba ahli desain/ rancangan pembelajaran, uji coba lapangan guru mata pelajaran Pendidikan Kewarganegaraan, uji coba lapangan siswa kelompok kecil (5 siswa), uji coba lapangan siswa kelompok besar (30 siswa) dapat disimpulkan bahwa produk pengembangam/perencanaan pembelajaran model pendidikan karakter yang diintegrasikan dalam mata pelajaran Pendidikan Kewarganegaraan di SDN Lawang 5 dan SDK ST Fransiskus Kecamatan Lawang Kabupaten
Malang telah memenuhi syarat/layak.

\section{Revisi Produk Pengembangan}

Berdasarkan uji coba produk pengembangan yaitu perencanaan pelaksanaan pembelajaran pendidikan karakter dapat diidentifikasi sebagai berikut:

a. Pada bagian C (Pendekatan dan Metode Pembelajaran) istilah "pendekatan" diganti dengan metode.

b. Pada Bagian D (Langkah-langkah Kegiatan).

1) Dalam kegiatan inti sub eksplorasi, bunyi teks "dalam kegiatan eksplorasi, guru:" dirubah menjadi "dalam kegiatan eksplorasi, guru melibatkan siswa secara aktif".

2) Dalam kegiatan inti sub elaborasi, bunyi teks "dalam kegiatan elaborasi, guru:" dirubah menjadi "dalam kegiatan eksplorasi, guru bersama siswa".

3) Dalam kegiatan inti sub konfirmasi, bunyi teks "dalam kegiatan konfirmasi, guru:" dirubah menjadi "dalam kegiatan konfirmasi, guru bersama siswa".

4) Dalam kegiatan penutup, bunyi teks "dalam kegiatan penutup, guru:" dirubah menjadi "dalam kegiatan penutup, guru bersama siswa".

c. Bagian E (Penilaian) sub "Format Kriteria Penilaian" ditambahkan "rubrik lain untuk peta".

c. Bagian E (Penilaian) sub "Format Kriteria Penilaian" ditambahkan "rubrik lain untuk peta".

\section{Revisi Produk Pengembangan oleh Ahli Isi}

Berikut adalah ringkasan revisi perencanaan pembelajaran berdasarkan masukan dan saran dari data hasil penilaian ahli isi.

\section{Revisi Produk Pengembangan oleh Ahli Desain}

Berikut ini Tabel 8 adalah ringkasan revisi perencanaan pembelajaran pendidikan karakter melalui pembelajaran mata pelajaran Pendidikan Kewarganegaraan bagi siswa Kelas VI di SDN Lawang 5 dan SDK ST. Fransiskus Kecamatan Lawang Kabupaten Malang. 
Tabel 4 Data Hasil Penilaian Guru Mata Pelajaran terhadap Model Pendidikan Karakter yang dalam Pembelajaran Pendidikan Karakter yang Diintegrasikan dalam Pembelajaran Mata Pelajaran Pendidikan Kewarganegaraan di Sekolah Dasar

\begin{tabular}{llllllll}
\hline No. & Aspek yang Dinilai & \multicolumn{4}{c}{ Skor } & & Keterangan \\
\cline { 2 - 5 } & & 1 & 2 & 3 & 4 & 5
\end{tabular}

\begin{tabular}{llll}
\hline A. Kerangka Isi Pembelajaran & & \\
\hline 1. & Kejelasan kerangka perencanaan pembelajaran & $\sqrt{ }$ & Sangat Baik \\
\hline 2 & Kemenarikan isi perencanaan pembelajaran & $\sqrt{ }$ & Baik \\
\hline B. Tujuan Pembelajaran & & \\
\hline 1 & Kejelasan Isi Tujuan Pembelajaran & $\sqrt{ }$ & Cukup \\
\hline 2 & Ketepatan rumusan-rumusan tujuan pembelajaran & $\sqrt{ }$ & Cukup \\
\hline 3 & $\begin{array}{l}\text { Kejelasan bahasa yang digunakan dalam tujuan pem- } \\
\text { belajaran }\end{array}$ & $\sqrt{ }$ & Baik \\
\hline
\end{tabular}

(1) Petunjuk Penggunaan Rencana Pembelajaran

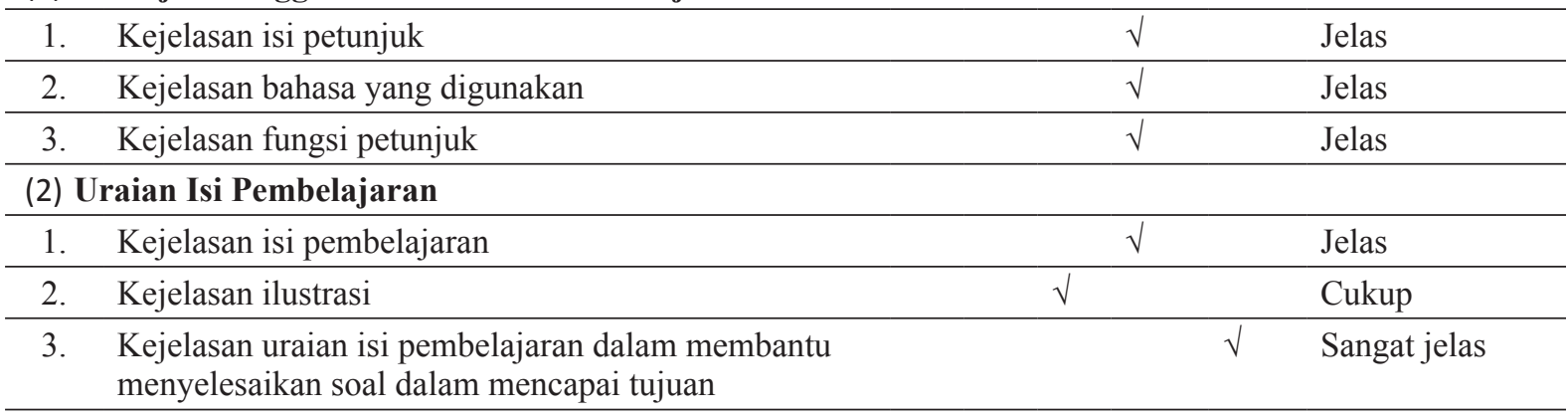

\section{(3) Soal Latihan/Tugas dan Kunci Jawaban}

\begin{tabular}{clrl}
\hline 1. & Kejelasan Tugas/Soal & $\sqrt{ }$ & Sangat jelas \\
\hline 2. & Kejelasan Bahasa yang digunakan & $\sqrt{ }$ & Sangat jelas \\
\hline 3. & Kesesuaian jumlah soal & $\sqrt{ }$ & Sesuai \\
\hline 4. & Kesesuaian kunci jawaban & $\sqrt{ }$ & Sangat sesuai \\
\hline 6. & Kejelasan kunci jawaban & $\sqrt{ }$ & Sangat jelas \\
\hline (4) Sumber/Bahan Belajar & Kesesuaian sumber/bahan belajar & & \\
\hline 1. & Ketepatan sumber/bahan belajar & $\sqrt{ }$ & Sesuai \\
\hline 2. & Jumlah skor (Nilai) & $\sqrt{ }$ & Tepat \\
\hline
\end{tabular}

Sumber: data diolah dari lapangan.

Tabel 5 Data Hasil Penilaian Siswa (Kelompok Kecil) terhadap Model Pendidikan Karakter yang Diintegrasikan dalam Pembelajaran Mata Pelajaran Pendidikan Kewarganegaraan di Sekolah Dasar

\begin{tabular}{|c|c|c|c|c|c|c|c|}
\hline \multirow[t]{2}{*}{ No. } & \multirow[t]{2}{*}{ Aspek yang Dinilai } & \multicolumn{5}{|c|}{ Skor } & \multirow[t]{2}{*}{ Keterangan } \\
\hline & & 1 & 2 & 3 & 4 & 5 & \\
\hline \multicolumn{8}{|c|}{ A. Kerangka Isi Pembelajaran } \\
\hline 1. & Kejelasan kerangka perencanaan pembelajaran & & & & & $\sqrt{ }$ & Sangat Baik \\
\hline 2 & Kemenarikan isi perencanaan pembelajaran & & & & $\sqrt{ }$ & & Baik \\
\hline \multicolumn{8}{|c|}{ B. Tujuan Pembelajaran } \\
\hline 1 & Kejelasan Isi Tujuan Pembelajaran & & & $\sqrt{ }$ & & & Cukup \\
\hline 2 & Ketepatan rumusan-rumusan tujuan pembelajaran & & & $\sqrt{ }$ & & & Cukup \\
\hline 3 & $\begin{array}{l}\text { Kejelasan bahasa yang digunakan dalam tujuan pembe- } \\
\text { lajaran }\end{array}$ & & & & $\sqrt{ }$ & & Baik \\
\hline
\end{tabular}




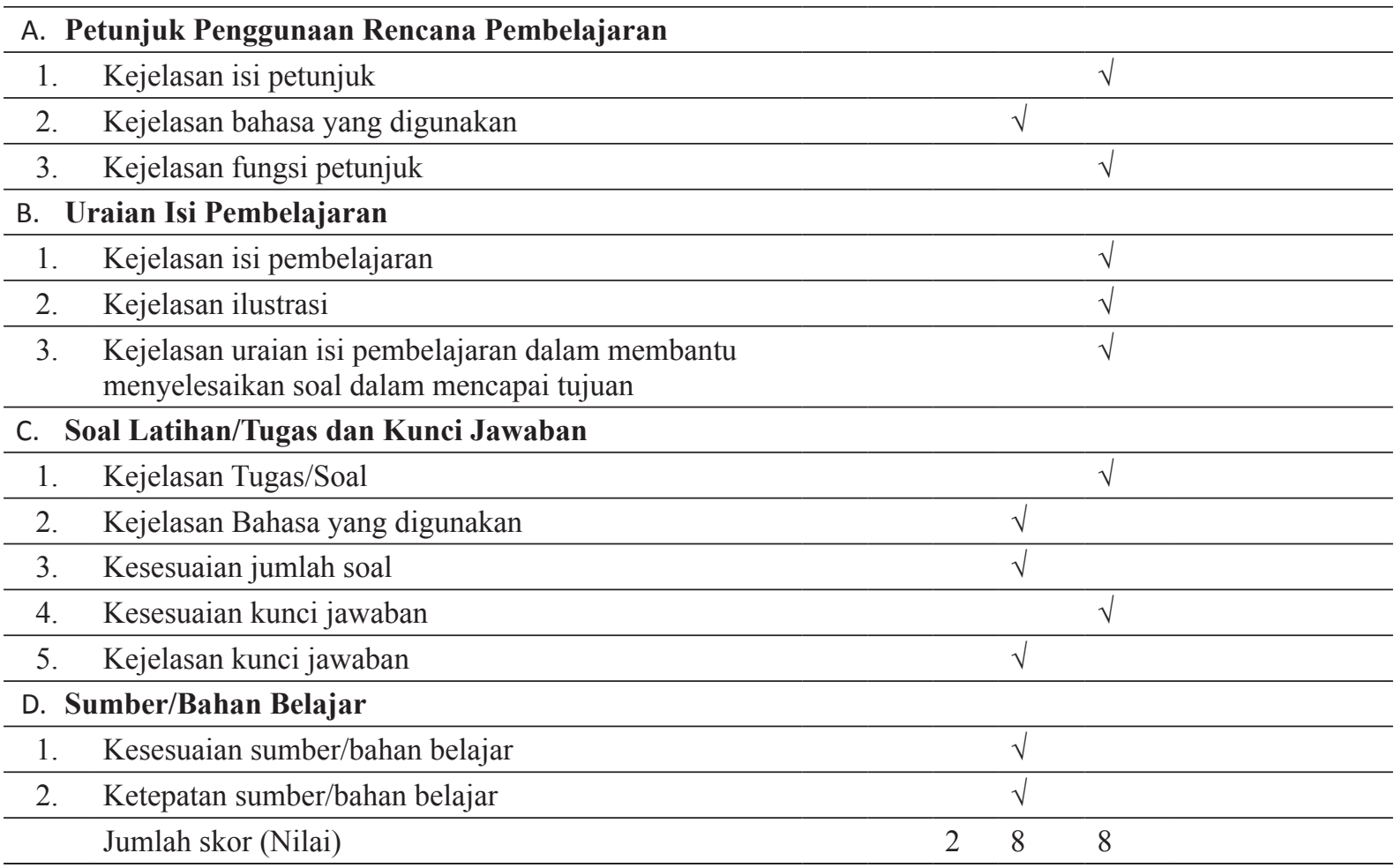

Tabel 6 Data Hasil Uji Coba Lapangan Tinjauan Siswa (Kelompok Besar)

\begin{tabular}{|c|c|c|c|c|c|c|c|}
\hline \multirow[t]{2}{*}{ No. } & \multirow[t]{2}{*}{ Aspek yang Dinilai } & \multicolumn{5}{|c|}{ Skor } & \multirow[t]{2}{*}{ Keterangan } \\
\hline & & 1 & 2 & 3 & 4 & 5 & \\
\hline \multicolumn{8}{|c|}{ A. Kerangka Isi Pembelajaran } \\
\hline & Kejelasan kerangka perencanaan pembelajaran & & & & & $\sqrt{ }$ & \\
\hline 2 & Kemenarikan isi perencanaan pembelajaran & & & & $\sqrt{ }$ & & \\
\hline 3 & Kejelasan Isi Tujuan Pembelajaran & & & $\sqrt{ }$ & & & \\
\hline 4 & Ketepatan rumusan-rumusan tujuan pembelajaran & & & $\sqrt{ }$ & & & Cukup \\
\hline 5 & $\begin{array}{l}\text { Kejelasan bahasa yang digunakan dalam tujuan pembe- } \\
\text { lajaran }\end{array}$ & & & & $\sqrt{ }$ & & Baik \\
\hline \multicolumn{8}{|c|}{ B. Petunjuk Penggunaan Rencana Pembelajaran } \\
\hline & Kejelasan isi petunjuk & & & $\sqrt{ }$ & & & \\
\hline & Kejelasan bahasa yang digunakan & & & $\sqrt{ }$ & & & \\
\hline & Kejelasan fungsi petunjuk & & & & $\sqrt{ }$ & & \\
\hline \multicolumn{8}{|c|}{ C. Uraian Isi Pembelajaran } \\
\hline & Kejelasan isi pembelajaran & & & $\sqrt{ }$ & & & \\
\hline & Kejelasan ilustrasi & & & & $\sqrt{ }$ & & \\
\hline & $\begin{array}{l}\text { Kejelasan uraian isi pembelajaran dalam membantu } \\
\text { menyelesaikan soal dalam mencapai tujuan }\end{array}$ & & & $\sqrt{ }$ & & & \\
\hline \multicolumn{8}{|c|}{ D. Soal Latihan/Tugas dan Kunci Jawaban } \\
\hline & Kejelasan Tugas/Soal & & & & $\sqrt{ }$ & & \\
\hline & Kejelasan Bahasa yang digunakan & & & & $\sqrt{ }$ & & \\
\hline & Kesesuaian jumlah soal & & & & & $\sqrt{ }$ & \\
\hline & Kesesuaian kunci jawaban & & & & $\sqrt{ }$ & & \\
\hline & Kejelasan kunci jawaban & & & & & $\sqrt{ }$ & \\
\hline
\end{tabular}




\begin{tabular}{lllll}
\hline E. & Sumber/Bahan Belajar & & & \\
\hline 1. & Kesesuaian sumber/bahan belajar & $\sqrt{ }$ & & \\
\hline 2. & Ketepatan sumber/bahan belajar & $\sqrt{ }$ & & \\
\hline & Jumlah skor (Nilai) & 8 & 7 & 3 \\
\hline
\end{tabular}

Sumber: data diolah dari lapangan.

Tabel 7 Ringkasan Revisi Rancangan Pembelajaran Pendidikan Karakter Berdasarkan Ahli Isi

\begin{tabular}{llll}
\hline No & \multicolumn{1}{c}{ Komponen Yang Dinilai } & \multicolumn{1}{c}{ Item Revisi } & \multicolumn{1}{c}{$\begin{array}{c}\text { Keterangan } \\
\text { Revisi }\end{array}$} \\
\hline 1. & Mekanisme pembelajaran & Mekanisme pembelajaan yang diperbaiki & Sudah direvisi. \\
2. & Materi perencanaan pembelajaran. & Materi perencanaan pembelajaran didetailkan. & Sudah direvisi. \\
3. & Kompetensi. & Sesuai kompetensi dengan evaluasi. & Sudah direvisi. \\
\hline
\end{tabular}

Tabel 8 Ringkasan Revisi Perencanaan Pembelajaran Pendidikan Karakter Berdasarkan Ahli Desain

\begin{tabular}{|c|c|c|c|}
\hline No & Komponen Yang Dinilai & Item Revisi & $\begin{array}{l}\text { Keterangan } \\
\text { Revisi }\end{array}$ \\
\hline 1. & Analisis Isi & $\begin{array}{l}\text { Analisis isi (Peta Isi) kurang detail bisa ditambah } \\
\text { uraiannya. }\end{array}$ & Sudah revisi. \\
\hline 2. & Secara umum padat isi. & $\begin{array}{l}\text { Pengaturan format page dan penambahan garis } \\
\text { pemisah antara materi dan tugas/tes. }\end{array}$ & Sudah revisi. \\
\hline 3. & Ilustrasi. & $\begin{array}{l}\text { Dibuat ilustrasi belajar siswa setiap perencanaan } \\
\text { pembelajaran. }\end{array}$ & Sudah revisi. \\
\hline 4. & Evaluasi & $\begin{array}{l}\text { Ditambahkan dalam RPP tentang pedoman penilaian } \\
\text { pendidikan karakter. }\end{array}$ & Sudah revisi. \\
\hline
\end{tabular}

\section{KESIMPULAN DAN SARAN}

\section{Kesimpulan}

Kajian produk dalam subbab ini difokuskan terhadap pengembangan perencanaan pembelajaran hasil rangkaian ujicoba yang telah dilaksanakan, meliputi: ujicoba ahli, ujicoba individu, ujicoba kelompok dan ujicoba lapangan menunjukkan hasil produk perencanaan pembelajaran pendidikan karakter yang diintegrasikan dalam pembelajaran mata pelajaran Pendidikan Kewarganegaraan. Uji coba produk perencanaan pelaksanaan pembelajaran dilakukan secara bertahap sesuai dengan tahapan yang telah direncanakan, mulai dari uji coba perorangan, uji coba kelompok kecil sampai dengan uji coba kelompok besar.

Setiap tahapan pengembangan telah disempurnakan, sehingga tercapai hasil yang sesuai dengan yang diharapkan. Aplikasi model pembelajaran dalam ujicoba lapangan menunjukkan hasil belajar berupa penguasaan nilai-nilai karakter bagi peserta didik berdasarkan penilaian guru yang mengajar mata pelajaran Pendidikan Kewarganegaraan. Dengan hasil capaian yang demikian, maka dapat dikemukakan dalam kajian ini tahapan pengembangan produk perencanaan pembelajaran pendidikan karakter dalam pembelajaran mata pelajaran Pendidikan Kewarganegaraan.

Pertama, pengembangan pendidikan karakter di sekolah dasar diawali dengan studi pendahuluan, studi pengembangan dan implementasi yang kemudian menghasilkan perangkat pendidikan karakter di sekolah dasar berupa perencanaan pelaksanaan pembelajaran. Nilai-nilai pendidikan karakter yang diinterasikan melalui pembelajaran mata pelajaran Pendidikan Kewarganegaraan antara lain meliputi nilai-nilai 
karakter sebagai berikut ini: dapat dipercaya (trustworthines), rasa hormat dan perhatian (respect), tekun (dilligence), tanggung jawab (responsibility), berani (courage), integritas (integrity), peduli (caring), jujur (fairness) dan kewarganegaraan (citizenship).

Kedua, produk pengembangan pendidikan karakter yang dikembangkan dalam penelitian dan pengembangan ini adalah berupa perencanaan pelaksanaan pembelajaran pendidikan karakter di sekolah dasar yang disusun oleh pengembang dengan mengintegrasikannya dalam pembelajaran mata pelajaran Pendidikan Kewarganegaraan.

Ketiga, perencanaan pelaksanaan pembelajaran yang dikembangkan sebagai pendidikan karakter ini terdiri atas komponen-komponen sebagai berikut: (1) Standar Kompetensi, (2) Kompetensi Dasar, (3) Tujuan Pembelajaran, (4) Karakter Siswa yang Diharapkan, (5) Materi Ajar, (6) Metode Pembelajaran, (7) Langkahlangkah Kegiatan, (8) Sumber/Bahan Belajar, dan (9) Penilaian. Produk pengembangan pendidikan karakter yang diintegrasikan dalam suatu perangkat perencanaan pembelajaran mata pelajaran Pendidikan Kewarganegaraan untuk siswa Kelas VI di Sekolah Dasar yang berupa RPP yang dikembangkan dengan pendekatan yang komprehensif, seperti penugasan, tugas kelompok, penggunaan gambar-gambar, klipping koran, dsbnya. Peserta didik memiliki respon yang sangat positif terhadap rancangan pelaksanaan pembelajaran, khususnya nilai-nilai karakter yang diharapkan yang diintegrasikan dalam pembelajaran mata pelajaran Pendidikan Kewarganegaraan, khususnya yang diterapkan terhadap siswa Kelas VI di SDN Lawang 5 dan SDK ST Fransiskus di Kecamatan Lawang Kabupaten Malang.

Keempat, pelaksanaan nilai-nilai pendidikan karakter yang dilaksanakan oleh guru dan diintegrasikan dalam pembelajaran mata pelajaran Pendidikan Kewarganegaraan terhadap siswa Kelas VI di SDN Lawang 5 dan SDK ST Fransiskus Kecamatan Lawang Kabupaten Malang didukung oleh iklim yang kondusif dengan menerapkan disiplin, keteladanan, ekstra kurikuler, kantin kejujuran, kegiatan Hari-hari Besar Keagamaan serta pendekatan yang bersifat penanaman (inkalkulatif) dan bukan indoktrinasi serta pembiasaan (habituation) sehari-hari di sekolah.

\section{Saran}

Untuk mengoptimalkan pemanfaatan rancangan pendidikan karakter dalam hal ini, mata pelajaran Pendidikan Kewarganegaraan, maka pengembang mengemukakan saran-saran sebagai berikut. Sebelum pelaksanaan pembelajaran dilakukan, guru hendaknya mempersiapkan diri dengan membaca petunjuk penggunaan perencanaan pelaksanaan pembelajaran pendidikan karakter yang diintegrasikan pada pembelajaran mata pelajaran Pendidikan Kewarganegaraan di sekolah dasar secara cermat, sehingga dalam pelaksanaan pendidikan karakter sesuai capaian yang nilai-nilai karakter yang diharapkan dalam perencanaan pelaksanaan pembelajaran yang telah disusun oleh guru.

Untuk menumbuhkan kreativitas guru dalam menerapkan nilai-nilai karakter dalam pembelajaran pendidikan karakter, maka guru menerapkannya dengan mengintegrasikan pada mata pelajaran yang relevan dengan memasukkan nilai-nilai karakter dengan mempertimbangkan karakteristik mata pelajaran yang diampunya serta dengan memperhatikan Kompetensi Dasar (KD) dalam perencanaan pembelajaran (RPP) yang disusun oleh guru.

Sebelum proses pembelajaran berlangsung, sebaiknya guru memperhatikan karakteristik mata pelajaran, kompetensi dasar serta pendekatan strategi pembelajaran yang diterapkan kepada siswa, sehingga perencanaan pembelajaran yang telah disusun dapat mencapai sasaran sesuai dengan capaian yang diinginkan, tidak hanya berdasarkan KKM (Kriteria Ketuntasan Minimal), tetapi juga nilai-nilai karakter yang harus dipahami siswa yang diintegrasikan dalam pembelajaran yang telah direncanakan.

Beberapa hal yang perlu disarankan untuk diseminasi produk ke sasaran yang lebih luas terhadap penggunaan rancangan pelaksanaan pembelajaran pendidikan karakter adalah sebagai berikut. Oleh karena produk pengembangan pendidikan karakter untuk peserta didik di sekolah dasar ini melalui beberapa kajian, penilaian dan uji coba kepada subjek yang tepat (ahli, guru dan siswa), maka pengembang akan memperbanyak model pendidikan karakter ini untuk digunakan dengan cakupan yang lebih luas. 
Produk pengembangan ini perlu diseminasikan kepada para guru tidak terbatas pada jenjang kelas-kelas tinggi tetapi juga kelas-kelas rendah di sekolah dasar.

Beberapa hal yang perlu disaranan untuk pengembangan produk lebih lanjut adalah sebagai berikut. Pada hakikatnya pendidikan karakter tidak terbatas pada mata pelajaran Pendidikan Kewarganegraan. Oleh karena itu, model pendidikan karakter perlu diterapkan pada semua mata pelajaran yang diajarkan di sekolah dasar. Perlu disusun lembar observasi yang dapat digunakan oleh guru untuk meneliti capaian nilai-nilai karakter yang telah diajarkan. Perlu dikembangkan lebih lanjut tentang pelaksanaan penilaian nilai-nilai karakter yang diintegrasikan pada mata pelajaran-mata pelajaran yang diajarkan di sekolah dasar.

\section{DAFTAR RUJUKAN}

Agung, I., Nadiroh \& Rumtini. 2011. Pendidikan Membangun Karakter Bangsa. Jakarta: PT Bestari Buana Murni.

Agustian, A.G. 2009. ESQ, Emotional Spritual Quoient. Jakarta: Arga.

Aman, S. \& Isa, A. Q. 2014. Tasawuf Revolusi Mental Zikir Mengolah Jiwa \& Raga. Banten: Penerbit Ruhama.

Asmani, J.M. 2012. Buku Panduan Internalisasi Pendidikan Karakter di Sekolah. Jogjakarta: Diva Press.

Borg, W.R. \& Gall, M.D. 1979. Educational Research: An Introduction. White Plain, N.Y.: Longman, Inc.

Budiastuti, E. 2010. Strategi Penerapan Pendidikan Karakter pada Pembelajaran Praktek Busana. Makalah disajikan pada Seminar Nasional 2010 "Character Building for Vocational Education". Jurusan PTBB, FT UNY 5 Desember 2010.

Chou, Mei-Ju, Yang, Chen-Hsin, \& Huang, Pin-Chen. 2014. The Beauty of Character Education on Preschool Children's Parent-Child Relationship. Procedia-Social and Behavioral Sciences 143
(2014) 527-533.

Ferdiawan, E. \& Putra, W.E. 2014. Esq Education for Children Character Building Based on Phylosophy of Javaness in Indonesia, $4^{\text {th }}$ International Conference on New Horizons in Education. Procedia-Social and Behavioral Sciences 106 (2013) 1096-1102.

Fitriah A., E. 2011. Manajemen Pendidikan Karakter di Sekolah Dasar Islam (Studi Kasus di Sekolah Dasar YIMA Islamic School Bondowoso). Tesis tidak dipublikasikan. Malang: Program Pascasarjana, Universitas Islam Negeri Maulana Malik Ibrahim Malang.

Ghufron, A. 2011. Desain Kurikulum yang Relevan untuk Pendidikan Karakter. Cakrawala Pendidikan, Mei 2011, Th. XXX, Edisi Khusus Dies Natalis Universitas Negeri Yogyakarta.

Marzuki, I. 2013. Pelaksanaan Pendidikan Karakter di Sekolah Dasar. Tesis tidak dipublikasikan. Surabaya: Universitas Negeri Surabaya.

Mulyatiningsih, E. 2011. Analisis Model-Model Pendidikan Karakter untuk Usia Anak-anak, Remaja dan Dewasa. Yogyakarta: FE Universitas Negeri Yogyakarta.

Nawawi, H. 1983. Administrasi Pendidikan. Jakarta: Gunung Agung.

Nuryatin, A. 2014. Pengembangan Model Pembelajaran Bahasa Indonesia Berbasis Pendidikan Karakter pada Pendidikan Dasar.

Suparno, P., Koesomo, M.Y., Titisari, D. \& Kartono, St. 2002. Pendidikan Budi Pekerti di Sekolah: Sebuah Tinjauan Umum. Yogyakarta: Kanisius.

Zuchdi, D., Prasetya, Z.K., \& Masruri, M.S. 2006. Pendidikan Karakter melalui Pengembangan Keterampilan Hidup dalam Kurikulum Persekolahan. Laporan Penelitian Hibah Pasca 2005-2006. Yogyakarta: Lembaga Penelitian UNY.

Wulandari, A.N., Sukestiyarno, Y.L. dan Sugiman. 2013. Pengembangan Karakter dan Pemecahan Masalah melalui Pembelajaran Matematika dengan Model TAPPS. Unnes Journal of Mathematics Education (UJME) 2 (3) (2013). Semarang: Universitas Negeri Semarang. 